\title{
Malay Rejection on Elimination of All Forms of Racial Discrimination
}

\author{
Suyatno Ladiqi ${ }^{1}$, Aizatul Anis binti Zuhari ${ }^{2}$ \\ \{yatno.ladiqi@gmail.com ${ }^{1}$, aizatulanis@gmail.com ${ }^{2}$ \} \\ University Sultan Zainal Abidin, Terengganu, Malaysia ${ }^{1,2}$
}

\begin{abstract}
After the change of the new government on last year on 14th General Election in May 2018, Malaysia is facing with a new administration, ideas and form of government after sixty years in the hand of previous government called as the Barisan Nasional (BN). After given the mandate by the Malaysian, the new government under the role of Pakatan Harapan $(\mathrm{PH})$ wanted to ratify the international convention known as International Convention on the Elimination of All Forms of Racial Discrimination (ICERD) under the United Nation (UN) that promotes states to eliminate all form of discrimination in the government ruling. However, the ratification of ICERD has created major wrath of the Malays and Bumiputras due to inconsistency in certain aspects of special privilege and rights of the Malays and Bumiputras embedded in Article 153 of the Constitutions. ICERD imply negatively to the 'Social Contract', Islam as the national religion of the state and the constitutional monarchy system in Malaysia. This can be sum up as the effort of the Malay to protect its 'Ketuanan Melayu' as their identity. This paper is meant to study the pros and cons of the ICERD towards the people and also to analyze the reactions of the Malays especially towards the ICERD issues.
\end{abstract}

Keywords: Ketuanan Melayu, ICERD, Article 153 of the Constitutions, Malaysia.

\section{Introduction} What is 'Ketuanan Melayu'? “ Tak kan Melayu hilang di dunia”- Hang Tuah (The Epic of
Hang Tuah)

Never should the Malay feel lost (Hilang) in the world is the famous saying from the prominent 'Laksamana' known as Malay warrior who lived in Malacca during the 15th century had motto possess the cosmopolitan spirit of the wise and pacifist Tuah (Farish Noor, 2009). The Ketuanan Melayu is best to understand as Malays and Bumiputeras are the people of the land or original people along ratifying the political power and certain special privileges to the Malays and Bumiputeras. However, this does not mean that the other races right are denied. All of the government subsidies, initiatives and budget are given equally. The Chinese and Indian are freely to build their temple, school and live freely in the land with guaranteed of the security. Although the idea itself predates Malaysian independence, the phrase Ketuanan Melayu did not come into vogue until the early 2000s decade. The misinterpretation of the terms leads to an understanding of discriminations and inequality in rights and power of the non-Malays. This would spark the fire of racial issues. Malaysian should learn from the history how Malays right deprived and take the toleration of the Malay rulers as a key to allow understanding ICERD in western perception, ICERD does give a great platform for equality 
for the state. However, in the Malaysian context, it goes against what embedded in the constitutions and social norms. Since Merdeka, Malaysia did not sign ICERD and the only country define racial religions which the Malays are defined in the Federal Constitution as Muslims, Malay, and Malay-speaking. The major reason why the public opinion of Malaysia rejects the ICERD are first because of religions, second because of what it called the 'Social Contract' and lastly about the Ketuanan Melayu.

\section{Literatur Review}

Gross violation of human rights such as discriminations and failure of the state to ensure the administration policy to not contradict with the concept of human rights is today has become common issues in the world. Many of the discrimination are the results of interstate conflicts and international views that particularly happened in most in a developing country. In the Nature and Causes of Racism and Racial Discrimination, a journal by Michael Banton stated that the idea of racism has been of great rhetorical power in assembling universal activity for political change in Southern Africa. It has instigated more than seventy-five percent of UN part states to progress toward becoming gatherings to the 'Worldwide Show on the Disposal of All Types of Racial Separation'. Antidiscrimination laws are intended to secure specific classes of individual's specific social circles from activities which have either the reason or the impact of disabling the activity of their human right (Banton, 1992). Many scholars focused on public opinion that directed to issues of discrimination against transgender people in the context of healthcare can lead to poor health outcomes and facilitate the growth of health disparities (Vijay, 2018).

An article from the Factors Associated with Medical Doctors' Intentions to Discriminate Against Transgender Patients in Kuala Lumpur, Malaysia found that transgender people are frequent targets of discrimination. Discrimination against transgender people in the context of healthcare can lead to poor health outcomes and facilitate the growth of health disparities. This study explores factors associated with medical doctors' intentions to discriminate against transgender people in Malaysia. Also, most of public opinion of Malaysia directed on the issues of racial discrimination in hiring fresh degree graduates in Malaysia through a field experiment in a journal entitled Discrimination of high degrees: race and graduate hiring in Malaysia, which then analysed differentials in call back for interview attributable to racial identity, while controlling for applicant characteristics, employer profile and job requirements which found that find that race matters much more than résumé quality, with Malays Malaysia's majority group - significantly less likely to be called for interview. Other factors, particularly language proficiency of employees, language requirements of jobs and profile of employers, influence employer biases. Applicants fluent in Chinese fare better, and Chinesecontrolled and foreign-controlled companies are more likely to favor Chinese résumés, indicating that cultural compatibility explains part of the discrimination (Lee and Khalid,2015).

Moreover, in the journal of Discrimination of high degrees: race and graduate hiring in Malaysia explain that in the last twenty years, economic and social policy in Malaysia has been dominated by discrimination in favor of the Bumiputras and against the Chinese and the Indians (Lee and Khalid,1991). In no other area of public policy has reverse discrimination been more acute than in higher education. The paper shows that past and present educational policies in Malaysia have resulted in allocative inefficiency while the distribution of incomes 
has widened (Tzannatos, 1991). Furthermore, on international levels, the public opinions only directed on the knowledge and support for an ASEAN Community in Indonesia, Malaysia, and Singapore. Thus, there are no such efforts to clarify the public opinion on the issues of international conventions or the most frequently debated on the International Convention on the Elimination of All Form of Discriminations (ICERD). The quite related and similar issues on ICERD can be found in journal Racial Vilification And ICERD In Australia which talks about Australia which is presently far from compliance with the requirements of Article 4a of the Convention on the Elimination of All Forms of Racial Discrimination. The State Acts, while covering some aspects of Article $4 \mathrm{a}$, do not comprehensively cover the requirements, and are additionally handicapped by the fact that only some of the States have enacted them, and their application necessarily ends at State borders. The legislation that would go the furthest to bring Australia into compliance is the Racial Hatred Act.

However, this Act has substantial shortcomings. Community fears about the effect of such an Act may further reduce its compliance with the requirements of the Convention. The Australian public needs to be fully informed about the Act, and the necessity for the Act, so that community concerns do not cause the Act to be further weakened, and so there is no community backlash to the implementation of such legislation (Johns,1995). In fact, there is no specific research has been done to study the ratification of international conventions which go against the constitutions, social contract, and society of Malaysia. Thus, this research is solely valid and have not yet been justified by any publications.

\section{Methodology}

The methodology adopted for this paper is purely from secondary sources. The data was obtained completely from reliable and trustworthy sources such as literature, books, journals, and other internet sources during the completion of this research on the Malay Rejection of ICERD in Malaysia. The methodology used is the qualitative method which involves the collection of the previous articles and other relatable sources for the research purposes which have been summarised and interpreted into new writing based on the gathered sources.

\section{Discussion}

\section{Malay responds with "Sarang Tebuan Jangan Dijolok"}

Just like the beehive, if you hit it the whole squad will come out and attack. This what it means by Malay saying "Jangan Tebuan Jangan Dijolok". The most recent issues hit the wall was the ratification of the International Convention on the Elimination of All Forms of Racial Discrimination (ICERD) is a United Nations convention which obligates its members to eliminate any form of institutional discrimination that is against humanity and to promote and encourage universal respect for and observance of human rights and fundamental freedoms for all, without distinction as to race, sex, language or religion. Understanding this in western perception, ICERD does give a great platform for equality for the state. However, in the Malaysian context, it goes against what embedded in the constitutions and social norms. Since Merdeka, Malaysia did not sign ICERD and the only country define racial religions which the Malays are defined in the Federal Constitution as Muslims, Malay, and Malay-speaking. 
Malaysia is unique in recognizing Islam as an official religion, inhibiting the spread of other religions to Muslims, recognizing Islam and Bumiputera privileges, scholarships and so on. This contradicts the spirit of ICERD. However, after the 14th general election lead to the formation of the new government where the issues of equality hit up in media as the new government lead by 'Pakatan Harapan' a political coalition ready to ratify the ICERD. Minister in the Prime Minister's Department, $\mathrm{P}$ Waytha Moorthy, reportedly said the government would ratify or confirm six forms of the international agreement including ICERD in the first quarter of next year. This sparks wrath of the Malays and pushed to the government to reject it.

Finally, Prime Minister Tun Mahathir Mohamed agree to not ratify the ICERD. However, the Parti Keadilan Rakyat (PKR) president Datuk Seri Anwar Ibrahim described it as reasonable for the government to postpone the ratification of the International Convention on the Elimination of All Forms of Racial Discrimination (ICERD) (Astro Awani, 2018). The word 'postpone' used by him does not satisfy the Malays and this resulted in the 'Himpunan Aman Bantah ICERD' or called 'white demonstration' on 8th December 2018. A massive rally involving PAS and UMNO members was held in the capital to object to the proposed ratification of the ICERD. PAS president Datuk Seri Abdul Hadi Awang said the gathering was aimed at declaring Malays and Islam's objections to the Federal Government's action which allegedly wanted to ratify or ratify ICERD. Meanwhile, Ahmad Zahid said UMNO would support the rally on Dec 8 and wanted a gathering of Ummah members to combine UMNO and PAS members in every state in the Peninsular. He said if there was no declaration from the government to reject the ICERD, the Malays across the country would rise up against the matter. Adding up, he claims that in the English dictionary, the words 'amuk' were borrowed from Malay showing that the Malays could rage if their rights were challenged. The gathering or also known as Himpunan 812 is a set of historical giants that never happened in Malaysian history where over a million Malays and Bumiputeras gathered on the streets. Many are surprised by this resurrection. In fact, they view the views of the Malays and do not expect the Malays to come down and be united. The gathering was a success and ended up in peace.

What are the lessons from the gathering? The issues affecting Islam and the position of the Malays and Bumiputeras are very sensitive. This fact fails to be understood by nonMuslims until they take the light on the actions that suffocate these two sensitive matters: Humiliation against the Prophet, the Yang di-Pertuan Agong, Islamophobia and Melayufobia is more fertile among non-Muslims in our country as the Malay Muslims are the majority. The disbelief and insecurity of the Muslim Malays are increasingly burning. The Malays have come to realize that the political dispute that has taken place so far has been a disadvantage. This is evident when two Malay Malay parties, namely UMNO and PAS and other parties are willing to cooperate and support to oppose the ICERD ratification. Since then, the unity and cooperation between these Malay Islamic parties have become stronger and more mature (Hespaini, 2019).

\section{Why Does The Malay Reject ICERD?}

The first major reasons why Malaysia did not ratify the ICERD are because of religion, Islam. Malaysia is unique in recognizing Islam as an official religion, inhibiting the spread of other religions to Muslims, recognizing Islam and Bumiputera privileges, scholarships and so on. Malaysia is an Islamic country that Article 3 (1) of the Federal Constitution provides that Islam is the religion of the Federation. However, at other times, other religions can be practiced peacefully and peacefully in any part of the Federation. Article 11 (1), the Federal 
Constitution provides that: "Every person is entitled to profess and practice his religion and, subject to Clause (4), extend it." Based on this provision, it is clear that Muslims are entitled to profess and practice the Islamic religion as a way of life. Clause (4) states that the law may be made to control or restrict the development of any other faith or belief in the religion of the Muslims. Islam is given the privilege and privilege of the Constitution. However, Islam does not restrict the right to freedom of religion for other faiths (Zamanai,2018). However, it does not mean that freedom is absolute because it is still subject to Article 11 (4) which restricts the spread of non-Muslims among Muslims. Freedom of human rights is also guaranteed by the Constitution under Part II. However, it is subject to certain conditions such as public order, public health, and moral principles as well as public rights (Zamani, 2018). The spirit of ICERD which celebrates the freedom of religions whereas embedded in the ratification of the ICERD would terrorize the positions of Islam in the constitutions which drag many Malays reject the ICERD. Malaysia was shaped as a Muslim country, not a secular country. Thus, the position of religion is prioritized.

Second, Malaysia has a unique system called 'social contract'. Along the way of reaching the independent, the rulers are aware of the differences by trying to tolerate cultural and identity issues. They understand that it was impossible to send all the non-Malays back their homeland but at the same time, thus, the idea of the Social Contract refers to trade-off through Articles 14-18 of the Constitution, pertaining to the granting of citizenship to the nonBumiputra of Malaya (particularly Malaysian Chinese and Indian), and this was carried over to Article 153 when Malaysia was formed on 16 September 1963, which grants the Malays special position in the country. The social contract embedded few of matters which are: (1) The Constitution explicitly grants the Bumiputra reservations of land, quotas in the civil service, public scholarships and public education, quotas for trade licenses, and the permission to monopolize certain industries if the government permits. In reality, however, especially after the advent of the Malaysian New Economic Policy (NEP) due to the racial riots of the May 13 Incident which occurred in 1969 when Malays held only 4\% of the Malaysian economy, Bumiputra privileges have extended to other areas; quotas are set for Bumiputra equity in publicly traded corporations, and discounts for them on automobiles and real estate ranging from $5 \%$ to $15 \%$ are mandated. (2) The Constitution also included elements of Malay tradition as part of the Malaysian national identity. The Malay rulers were preserved, with the head of state, the Yang di-Pertuan Agong, drawn from their ranks. Islam would be the national religion, and the Malay language would be the national language. The justification of the 'social contract' in a way can be seen as racist. But, as mentioned above it talk about equity rather than equity. Tunku Abdul Rahman sees the weakness of the Malay people resulted from British break a ruling principle had to make Malays less in their own land. The same equality cannot be given as a huge gap in the economy was serious and this would disadvantage the Malays. A legacy of the British colonial system "break and rule" was the division of Malaysians into three groups according to ethnicity. The Malays were concentrated in their traditional villages, focusing mainly on agricultural activities and living in poverty, in the other hand the Chinese dominated Malaysian commerce and developed as part of the larger bamboo network, a network of overseas Chinese businesses operating in the markets of Southeast Asia that share common family and cultural ties. Educated Indians took up professional roles such as those of doctors or lawyers, while the less well-off worked the plantations. and keep harmony.

To sum up, the ratification of ICERD is strongly inconsistency with the religion, social contract and Ketuanan Melayu concept. The major issues are religion, as Malaysia is an Islamic country and there are some contradictions in the ICERD articles. Islam prohibits the 
LGBT practice while the ICERD speaks for freedom of ideas which nurturing the LGBT. Furthermore, the social contract of Malaysia has stated some special rights in the constitution in Article 153 the special rights of Malays and Bumiputra. Looking in ICERD perspective, Article 153 is seeming to discriminate other races which special privileges are given to the Malays and Bumiputra. However, this concept had been agreed in the social contract thus clearly shown that the ICERD is contradicting to the social contract and constitutions. Furthermore, the word Ketuanan Melayu is closely related to the ICERD as it portrayed as just to protect the rights of Malay and can be translated as discrimination. However, its just matters of idea believing that Malaya is the people of the land and did not have such a big degree to discriminations. Thus, the ratification of ICERD is against the constitution and contrary to the Malaysia social context. Thus, the public opinion of Malaysia agrees and has driven the government to not ratify the CVERD.

\section{Conclusion}

The real question is does really Malaysians living in inequality? Looking in Forbes magazine reported in Malaysia's 50 Richest views the top 10 richest men in Malaysia are held by many non-Malays putting Robert Kuok at the top of the list. In fact, numbers of the religious institution of non-Muslim rise up to $45 \%$ and mosque as to $55 \%$ which is relevant as Islam as the religion of the country (Abdullah, 2009). For many years since the independent, the rights of non-Malay are secured in the constitution to reach the equity but the Ultrakiasu thinkers still want more and even try to liberalize every aspect of the state. Taking Singapore as an example which In Article 152 of the Constitution of Singapore entitled 'Minorities and special position of Malays', it is stated that it shall be the responsibility of the Government constantly to care for the interests of the racial and religious minorities in Singapore and the Government shall exercise its functions in such manner as to recognise the special position of the Malays, who are the indigenous people of Singapore, and accordingly it shall be the responsibility of the Government to protect, safeguard, support, foster and promote their political, educational, religious, economic, social and cultural interests and the Malay language' (Hassan, 2013). Sadly, and quite obviously, Article 152 has not actually made much of a difference to the development of the Malays in Singapore. The truth is Article 152 is nothing but purely symbolic. Sure, the national anthem is still in the Malay language.

The issue of ICERD has been a shock and sparks the wrath many of Malaysian especially Malays and Bumiputra. The issue had finally resulted in non-ratification by the government due to public opinions. It is first to understand that the ICERD is really inconsistency with the Malaysia context in aspects of constitution agreed in the social contract, the national religion which is Islam and the society of Malaysia itself. It is no doubt that the ICERD does have a positive value, however, the application in Malaysia is not parallel to Malaysia's definitions. Furthermore, the ICERD is based on the western concept and Malaysia as a state located from the east strategically in "Nusantara" bear its own understanding of certain concepts. This shows that not all of the western ideas are the best and does not always provide a solution to another state.

Moreover, Malaysia really wanted to secure its identity as the state are pluralistic and multicultural in character. Thus, many Malays did not agree as this seems like a threat to towards their identity. Preservation of identity has become even more challenging with the rapid of globalization. Also, the public opinion of Malaysia strongly put the domestic law first 
rather than the urge in international law which shows its strong sovereignty. The selfdetermination of Malaysia also showed by the public opinion which rejects international matters which inconsistency with the norms. Also, Article 153 is one of the main points that address the special rights of Malays and Bumiputra inconsistence with ICERD. Article 153 was created to protect the rights and superiority of Malays and Bumiputra without discriminates other race rights. Thus, it concerns the concept of equity in the circle if fairness rather than equality which stressed equality. Not all rights can be counted in terms of equality.

To sum up, the public opinion of Malaysia had finally reserved the sovereignty and selfdetermined of the state. Even though the many aspects of the ICERD is correct, but Malaysia just loves to be in its own way. Plus, there are no such discrimination or human right issues in Malaysia thus this may become proof that its domestic regulation operated at its best.

\section{Acknowledgement}

This paper is collaboration research at the Faculty of Law and International Relations, Universiti Sultan Zainal, Malaysia. The authors thank stakeholders of faculty who supported finishing and presenting the paper to the conference.

\section{References}

\section{Books}

[1]. Deneen. (2018). Why Liberalism Failed. Institute of advance study, University of Virginia.

[2]. Derex Croxton (2013). Westaphalia : The Last Christian Peace. Palgrave McMillan

[3]. Farish A. Noor (2014). What Your Teacher Didn't Tell You. Matahari Books. Petaling Jaya.

[4]. Hasnah H. (2010). Isu-isu Negara Bangsa Abad ke-20. University Malaysia Pahang. Pahang.

[5]. Lipman (1992). Public Opinion. Publication New York, Harcourt, Brace and Co

[6]. M.R.T. Abdullah (2011). Masih Adakah Ketuanan Melayu. Dinamika kreatif Publication. Kuala Lumpur

[7]. Manaf. H.A (2009). Kontrak Sosial. Utusan Publication. Selangor

[8]. Y. Ismail (1986). Kekuasaan dan Ketuanan Melayu. Dinamika Kreatif Publication. Selangor.

[9]. Z. Hassan (2013). Cuit Dilema Melayu Moden, Kuala Lumpur: Utusan Publication

\section{Articles}

[1]. Amaruddin (2018). Perhimpunan besar-besaran 8 Disember bantah ICERD. Retrieved from https://www.bharian.com.my/berita/nasional/2018/11/499267/perhimpunan-besar-besaran-8 disember-bantah-icerd. (Accessed 20 Jun 2019)

[2]. Aminuddin Yahya (2016). 'Himpunan bantah ICERD: Apa pengajaran daripadanya?' Retrieved from https://www.ismaweb.net/2019/02/26/himpunan-bantah-icerd-apa-pengajaran-daripadanya/. ((Accessed 20 Jun 2019)

[3]. Hespaizi Zain (2018). 'Malaysia Kini : Himpunan bantah Icerd tamat sejam lebih awal'. Retrieved from https://www.malaysiakini.com/news/455306. (Accessed 20 Jun 2019)

[4]. Kyoto University (2002). Malaysia: The Cost of Race Economics. Retrieved from https://kyotoreview.org/issue-1/malaysia-the-cost-of-race-economics/ (Accessed 20 Jun 2019)

[5]. Vijay (2018). Factors Associated with Medical Doctors' Intentions to Discriminate Against Transgender Patients in Kuala Lumpur, Malaysia. Retrieved from https://www.liebertpub.com/doi/abs/10.1089/lgbt.2017.0092. (Accessed 20 Jun 2019).

[6]. Wakerly and Rusell, (2016). What the Heck Does "Equity" Mean?. Retrieved from https://ssir.org/articles/entry/what_the_heck_does_equity_mean. (Accessed 20 Jun 2019). 


\section{Journal}

[1]. Johns (1995). Racial Vilification And Icerd. in Australia Murdoch University Electronic Journal of Law Volume 2, Number 1 (April 1995).

[2]. Lee, Khalid (1991). "Economy Discrimination of high degrees: race and graduate hiring in Malaysia". Journal of the Asia Pacific. Volume 21, 2016 - Issue 1.

[3]. Tzannatos, (2018). "Reverse racial discrimination in higher education in Malaysia: Has it reduced inequality and at what cost to the poor?" Elsevier. International Journal of Educational Development, Volume 11, Issue 3, 1991, Pages 177-192. 